\title{
MECHANICAL PROPERTIES OF GRAIN IN SILOS FOR SIMULATION DESIGNS
}

Doi:http://dx.doi.org/10.1590/1809-4430-Eng.Agric.v36n4p 573-580/2016

\section{JOSÉ P. LOPES NETO ${ }^{1 *}$, JOSÉ W. B. DO NASCIMENTO ${ }^{1}$, JORDÂNIO I. MARQUES ${ }^{1}$, CARLOS A. DA COSTA ${ }^{1}$}

\begin{abstract}
For the calculation of silos structures it has been used new methods and computational tools that require mechanical properties knowledge that are still unknown for most storable materials, especially grains. In this context, we aimed to determine the mechanical properties of rice and beans grains with moisture contents of 10, 12, and 14\% by applying four compressive loads $(5,10,15$ and 20). The determined mechanical properties were Pois son's ratio $(v)$, Modulus of Elasticity (E), and the dilatancy angle $(\psi)$. The procedure consisted in the application of the load in compression cell, adapted from MOLENDA \& STASIAK, aiming to simulate loading and unloading of silos. We observed that the Poisson's ratio calculated for both loading and unloading, presented higher values than the experimental values, with the increase of their moisture content; the experimental elastic modulus presented higher values than the calculated ones, and both increased their values with the increase of their moisture content; the dilatancy angle decreased with the increase of moisture content and compressive loads.
\end{abstract}

KEY WORDS : Poisson's coefficient, compression, modulus of elasticity, silos, simulation.

\section{INTRODUCTION}

The storage, handling and processing of granular products are necessary procedures in various industrial sectors and are interesting to various sciences and technology braches, such as physics, chemistry, mechanics, agriculture and engineering. The necessary procedures for the proper storage and process of granular products must combine the basic conditions such as predictable and safe operations and high quality of finished products, and due to the globalization of these processes, theses industries have found themselves under constant pressure to reduce costs without affecting their products quality (HORABIK \& MOLENDA, 2014).

According to LOPES NETO et al. (2013), among the main difficulties faced by the ind ustries that work with storage products, there is the formation of cohesive arches that prevent partially or completely the unloading and it is intrinsically related to the silos geometries and hoppers as well as the physical properties, the flow of solid products and the environment conditions such as atmospheric pressure, temperature and relative humidity.

The use of numerical simulation tools on previous studies has as main focus the improvement in the transport processes and handling of storable products. However, for these simulations to be carried out is necessary to know the mechanical properties of these products and their behaviour during rupture. (GUSTAFSSON et al2013).

RAMÍREZ et al. (2010) ensure that the data about the mechanical properties as modulus of Elasticity (E), Poisson's ratio $(v)$ and the dilatancy angle $(\psi)$ of the storable products are important to these simulation tools. However, according to MOYA et al. (2013), this information is not commonly found in literature. Therefore, values found by various methods or even assuming values from other properties, which may result in inaccuracies in the current models.

Among the simulation techniques of pressure and flow in silos, we highlight the modelling by discrete elements that allow the mechanical, static and dynamic behaviour of storable products to be simulated (GONZÁLEZ-MONTELLANO et al., 2011). This technique is based on a scheme where each particle of a system is simulated individually - a requirement when dealing with granular products. The movement of this granular system is modelled by adopting the classical Newtonian

\footnotetext{
${ }^{1}$ UFCG/Campina Grande - PB, Brasil.

*Corresponding author. E-mail: lopesneto@ deag.ufcg.edu.br

Received in: 8-25-2015

Accepted in: 4-5-2016
} 
laws of motion. The particles, when in motion, are considered rigid and in constant contact with each other, whose interaction is monitored by force and displacement transducers, expressing the force involved in this system.

In order to contribute to greater accuracy of computer simulation models in the industrial storage area, the present study aimed to determine the mechanical properties of two agricultural products with moisture content, through uniaxial compression tests.

\section{MATERIAL AND METHODS}

The modulus of Elasticity (E), Poisson's ratio $(v)$ and the dilatancy angle $(\psi)$ of two storable products, rice and bean grains in moisture contents of $10 \%, 12 \%$ and $14 \%$ were determined. For the tests, we built a cell to determine the mechanical properties consisting of two semicircles (A attachment point to the base and B - free end) with $125.0 \mathrm{~mm}$ of radius and $200.0 \mathrm{~mm}$ of height, made of steel plate with $6.35 \mathrm{~mm}$ of thickness (Figure 1). The tested compression cell model was adapted from MOLENDA \& STASIAK (2002).

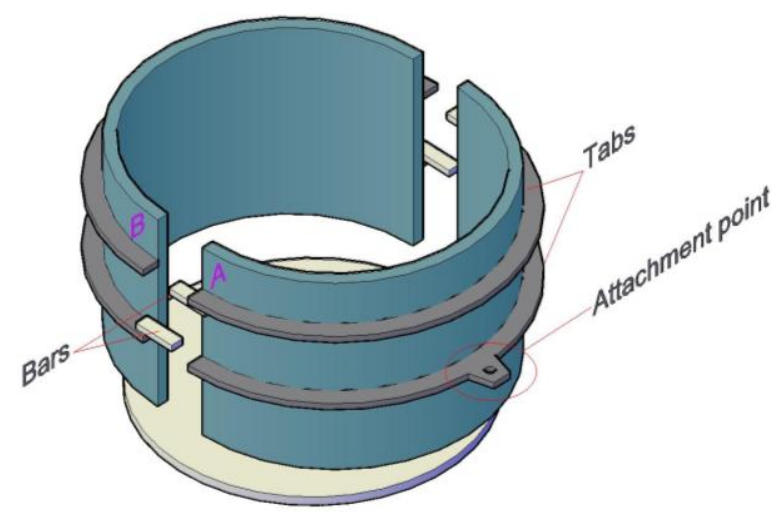

FIGURE 1. Compression cell for mechanical properties determination.

The cell had two side tabs where were placed four aluminium bars with average modulus of elasticity of $16.8 \mathrm{GPa}$ (value found in traction trial), and each bar was instrumented with an electrical extensometer connected to a data acquisition system Spieder8 $600 \mathrm{~Hz}$ manufactured by HBM, whose data were analysed by Catman software, 4.5 version. On the top of the cell was also instrumented with a $30 \mathrm{kN}$ load cell and a unidirectional displacement sensor to record the compression force acting on the mass and its vertical displacement (Figure 2).

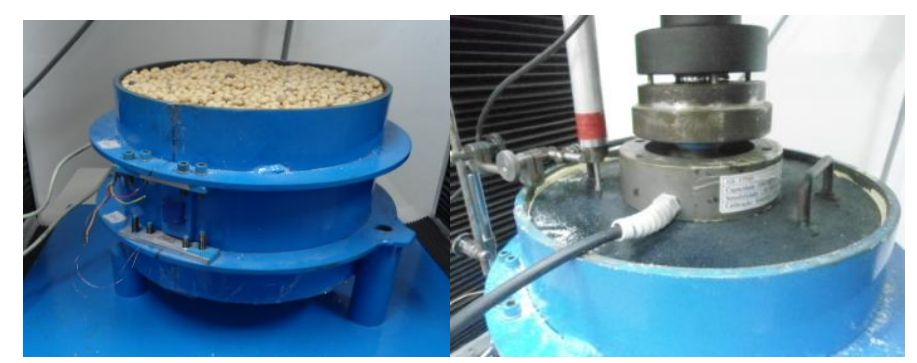

FIGURE 2. Cell instrumented and filled with grains.

We used a universal testing machine Autograph AG-IS Shimadzu model of 100kN capacity for the test. The experimental procedure consisted in applying compressive loads of $5 \mathrm{kN}, 10 \mathrm{kN}$, $15 \mathrm{kN}$ and $20 \mathrm{kN}$ on each product, for each moisture content. Briefly, the compression was applied in the product until the value of $5 \mathrm{kN}$ and subsequent the equipment was unloaded. Then, the product was removed from the cell, manually uncompressed and reapplied the previous load. This procedure was repeated four times for the four chosen compression loads.

Each test consists basically of two stages of loading and unloading. This last one was divided in other two stages, the first considered rectilinear and the second curvilinear. The loading 
characterized by the products compaction is equipped with two simultaneous phases in the material: reversible phase (elastic) and irreversible phase (plastic), based on the elastic-plastic theory. The $\mathrm{K}_{0}$ factor calculated in the loading stage represents the relation between horizontal pressure, $\sigma_{\mathrm{x}}$, and vertical pressure, $\sigma_{y}$, thus having a linear dependence. For the loading phase, the Poisson's ratio $\left(v^{*}\right)$ could be found by the [eq. (1)]:

$$
\mathbf{v}^{*}=\frac{\mathbf{k}_{0}}{1+\mathbf{k}_{0}}
$$

that,

$v^{*}$ - Poisson's ratio in loading,

$\mathrm{k}_{0}$ - represent the relation between the horizontal and vertical pressure.

The second stage of the test (unloading) was divided in two stages; in the first, the linear fraction (rectilinear) is characterized by elastic deformation; in this stage the information about the elastic constant is extracted (modulus of elasticity - E, and Poisson's ratio - v); and the second stage is characterized by elastoplastic deformation. We consider that the material is reversible and then ruled by the fundamental law of Hooke.

The elastic constants were determined from the experimental data of the linear stage of unloading, obtained by the relation between horizontal pressure $\left(\sigma_{\mathrm{x}}\right)$ and vertical pressure $\left(\sigma_{\mathrm{y}}\right)$, thus considering the constants (elastic state of tension). Through the linear regression procedure the experimental values were determined by the slope of the straight line, the constant $\mathrm{A}$, and the Poisson's ratio (v) found by the [eq. (2)] below:

$$
\mathbf{v}=\frac{\mathbf{A}}{1+\mathbf{A}}
$$

where,

$v$ - Poisson's ratio in the unloading,

A - elastic constant.

The modulus of elasticity (E) was determined by the $\varepsilon_{y}\left(\sigma_{y}\right)$ relation of the [eq. (3)], with experimental values of $\varepsilon y$ and $\sigma_{\mathrm{y}}$ and by the Poisson's ratio $(v)$, determined as described in the [eq.(2)]. The dilatancy angle $(\psi)$ used to determine the influence of the pressure distributions on the wall of the silo during the loading and unloading was determined using the values of vertical and horizontal deformation, as exposed by the [eq. (4)]. Further details of the applied methodology can be found in COSTA et al. (2014).

$$
\varepsilon_{y}=\frac{\sigma_{y}}{E}\left(1-\frac{2 v^{2}}{1-v}\right)
$$

where,

$\varepsilon_{\mathrm{y}}$ - vertical deformation;

$\sigma_{\mathrm{y}}$ - vertical pressure;

E - modulus of elasticity,

$v$ - Poisson's ratio.

$$
\psi=\frac{\frac{\Delta \varepsilon_{y}}{\mathbf{h}_{0}}}{\frac{\Delta \varepsilon_{x}}{\mathbf{L}}}
$$

where, 
$\psi$ - dilatancy angle, $\left(^{\circ}\right)$;

$\Delta \varepsilon_{\mathrm{y}}$ - Variation in the vertical deformation over time, $\mathrm{m}$;

$\Delta \varepsilon_{\mathrm{X}}$ - Variation in the horizontal deformation over time, $\mathrm{m}$;

$\mathrm{h}_{0}$ - Initial height of the sample, $\mathrm{m}$,

$\mathrm{L}$ - Initial length of the sample, $\mathrm{m}$.

\section{RESULTS AND DISCUSSION}

We observed in Figure 3 that the modulus of elasticity found for the grains of rices showed behaviour in accordance with the increase of values whenever a new charge was added. Numerically, the lowest values were found in grain with moisture content of $12 \%$, indicating less resistance to fracture in this moisture.

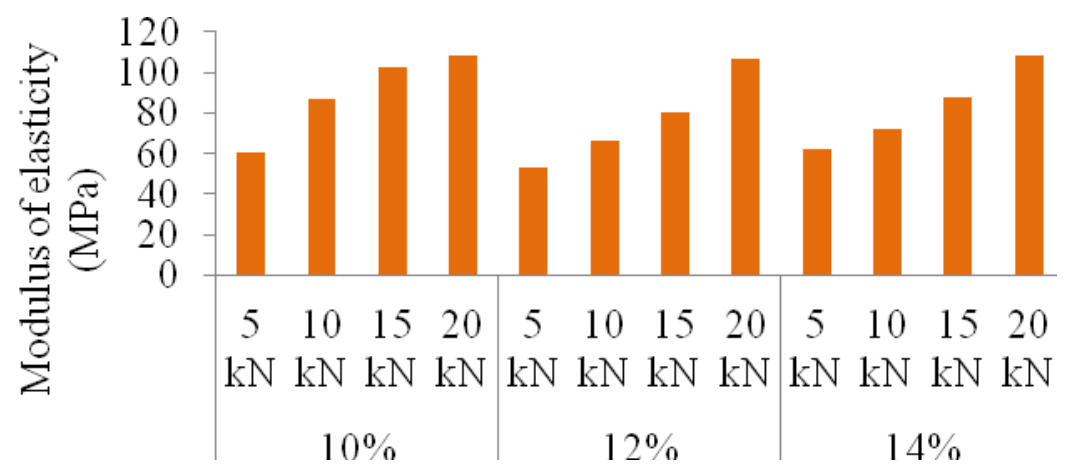

FIGURE 3. Modulus of elasticity for grain of rice.

When STASIAK et al. (2011) determined the modulus of elasticity for canola and using a compressive load of $10 \mathrm{kPa}$, they conclude that the values decreased when the moisture content increased, a fact that corroborated partially with the results of this study. A difference between the two studies that should be highlighted is the difference in the shape of the two products, the grain of rice has a more oblong shape, which can interfere with many factors such as, for example, its resistance to rupture.

For the bean, Figure 4, we observed an increase of the modulus of elasticity with the loads increase, the lowest values of $40.8 \mathrm{MPa}$ obtained to the load of $5 \mathrm{kN}$ and the highest value of $96.8 \mathrm{MPa}$ to the load of $20 \mathrm{kN}$, representing an increase of $58 \%$ between the two loads for the product with $10 \%$ of moisture. We found the lowest values of the modulus of elasticity in the moisture of $14 \%$, indicating a reduction in resistance with the increase of water content in the material.

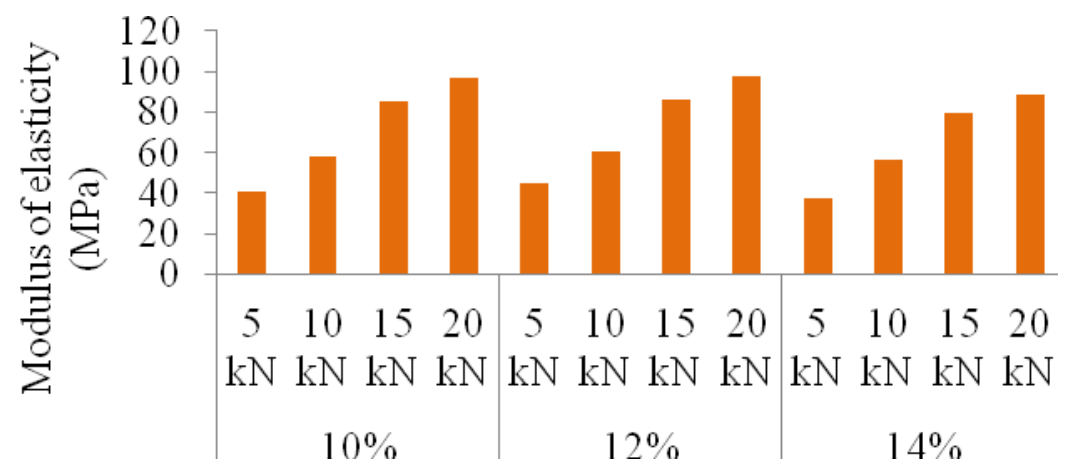

FIGURE 4. Modulus of elasticity for bean. 
WANG \& LI (2014) quote that variations found for modulus of elasticity of grains can be explained due to the influence of several factors such as macroscopic density of particles, tension state imposed to the tested mass, tension history, variation in particle size fraction, differences between the form factor and roughness of the particles, union power of the material membranes, among others. This statement can be adopted as reference in order to explain the variation observed in Figure 4 because the load increase tends to affect the characteristics mentioned above.

In full scale, the compressive loads developed in the storage process can also change some properties, in special the particle size distribution and shape of the material. In the case of agricultural products, these changes, especially in the product shape with higher moist ure content, may result significant changes in its mechanical properties (AL HATTAMLEH et al., 2013).

In Figure 5, we can observe that the values found for the Poisson's ratio $\left(v^{*}\right)$ calculated for the grain of rice with $10 \%$ of moisture showed an increase of the values up to $15 \mathrm{kN}$ in the loading stage. The $v^{*}$ for loading showed the same behaviour for the same stage to $12 \%$ of moisture. For the moisture content of $14 \%$, the values of $v_{\exp }$. showed oscillation, with the highest values for the loads of $5 \mathrm{kN}$ and $15 \mathrm{kN}$ and the lowest values for the loads of $10 \mathrm{kN}$ and $20 \mathrm{kN}$, with an average value of 0.1 .

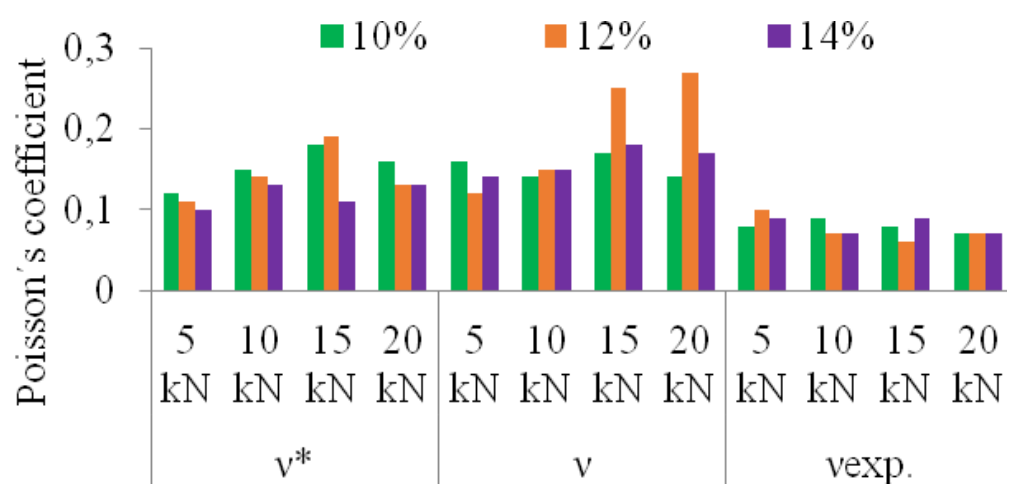

FIGURE 5. Poisson's coefficient for grain of rices.

MOLENDA \& STASIAK (2002) identified the maximum value for the Poisson's ratio $(v)$ of 0.22 , obtained for wheat grains with moisture content of $10 \%$; when GUSTAFSSON et al. (2013) studied the possibilities of solid material rupture they determined the average coefficient of 0.21 and this value is within the limit from 0.15 to 0.35 , quoted by the authors.

For the design projects, the POLISH STANDARD - PN-89/B-03262 recommends the use of a Poisson's ratio of 0.4 for agricultural products. MOYA et al. (2013) applied the same loads used in this study to determine the Poisson's ratio for corn, lentils and wheat grains, where they concluded that the value of this property tend to decrease with the applied load increase, an opposite fact to the one observed in this study. In numerical terms, the authors found values ranging from 0.29 to 0.34 , superior numbers to the ones showed here to bean and below the value of 0.4 , recommended by the POLISH STANDARD - PN-89 / B-03262 (1989).

Due to the wide variety of agricultural products, with even greater range of differences when analysed their properties such as shape, weight, size, type of surface, among others, it is possible the representation of the Poisson's ratio for agricultural products by only a single value, as recommended by the Polish norm, it is not the most appropriate condition, therefore being necessary the determination of specific values for each of them.

In figure 6, we can observe that the Poisson's ratio values calculated for the loading and unloading showed similar behaviour for the three moisture contents in which the values increased with the increase of the compressive load. As for the experimental Poisson's ratio ( $v_{\exp }$.), we registered an inverse order to each value of applied compression, with maximums for the lower load $(5 \mathrm{kN})$ and minimums for the higher load $(20 \mathrm{kN})$. This phenomenon can be explained by excessive 
loss of stiffness characteristic of agricultural products, especially bean, when submitted to higher moistures, beyond its cylindrical shape, allowing greater distribution of internal tension at the compression time and, consequently, higher compressive effect.

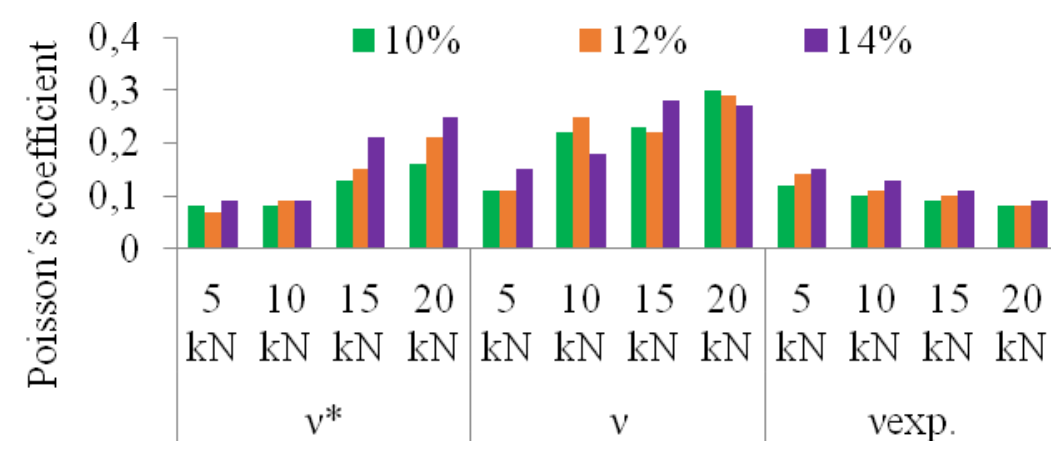

FIGURE 6. Poisson's coefficient for beans.

For the $10 \%$ moisture content, the $v^{*}$ for the loading stage did not show significant variation to the initial loads, reaching a value of 0.16 to $20 \mathrm{kN}$ load, which represents a $50 \%$ increase. The $v_{\text {exp }}$. showed, for the $5 \mathrm{kN}$ load, its highest value of 0.12 , suffering a decrease with the increase of load, until it reaches the lowest value of 0.08 , a trend that was already observed by MOYA et al. (2013).

When STASIAK et al. (2010) worked with canola for four moisture contents and using the $100 \mathrm{kPa}$ pressure, they found that the elastic constants obtained tended to decrease with the increase of the product moisture. These authors found, for the Poisson's ratio calculated for the loading stage, the values of $0.27,0.26$ and 0.23 for the moisture contents of $9 \%, 12 \%$ and $15 \%$, respectively. This reduction effect of the property with the increase of moisture content is corroborated with the Modulus of Elasticity results of this study, but it is in disagreement with the recorded for the Poisson's ratio, requiring therefore confirmation by new tests.

For the moisture content of $12 \%$, the Poisson's ratio values in the unloading (v) were superior to all loads, when compared to the loading stage. For the $v_{\text {exp., }}$ the highest value $(0.15)$ was recorded for the combination of lower load with higher moisture content. Referring only to loads, we can see

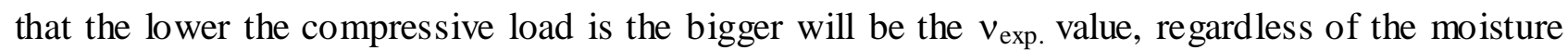
content analysed.

The Figure 7 illustrates the dilatancy angle values $(\psi)$ of grain of rices, where we observe the reduction in the dilatancy angle $(\psi)$ with the increase of the compressive load and simultaneously the increase of its value that raised the moisture content in the material; and the highest value for $5 \mathrm{kN}$ load and humidity of $14 \%$ equal to $28.5^{\circ}$. This phenomenon agrees with the one registered by CHAKRABORTY \& SALGADO (2010) that observed the dilatancy angle $(\psi)$ of sand grains tend to reduce due to the density variation and the increase of compression pressure.

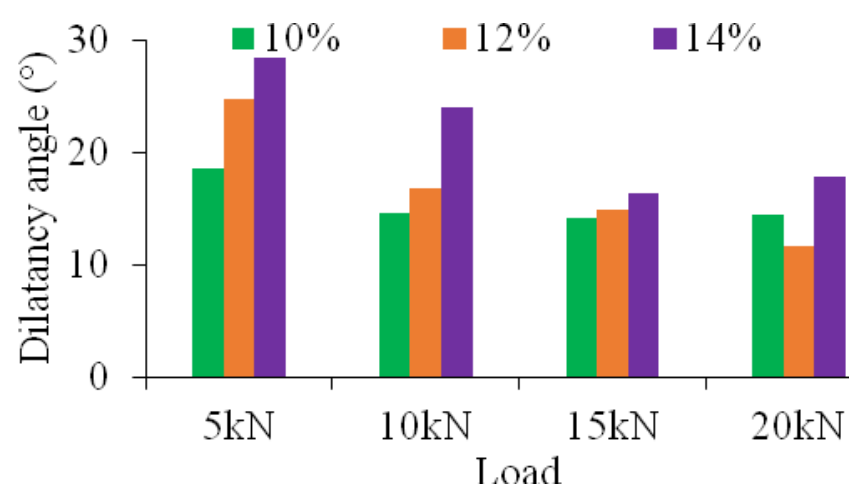

FIGURE 7. Dilatancy angle for grain of rices. 
The dilatancy angle $(\psi)$ values obtained for the moisture content of $12 \%$ showed decrease with the highest value $\left(24.83^{\circ}\right)$ for $5 \mathrm{kN}$ and the lowest value $\left(11.69^{\circ}\right)$ for $20 \mathrm{kN}$, difference of $52.92 \%$; moreover, for the same moisture content we observed that the value obtained for $20 \mathrm{kN}$ is still lower than the $10 \%$ moisture content, for the same load.

In Figure 8, where we can observe that the dilatancy angle $(\psi)$ values found for bean with moisture content of $10 \%$ were intermediate between the remaining moisture contents tested, which may be taken with a reference value for simulations number.

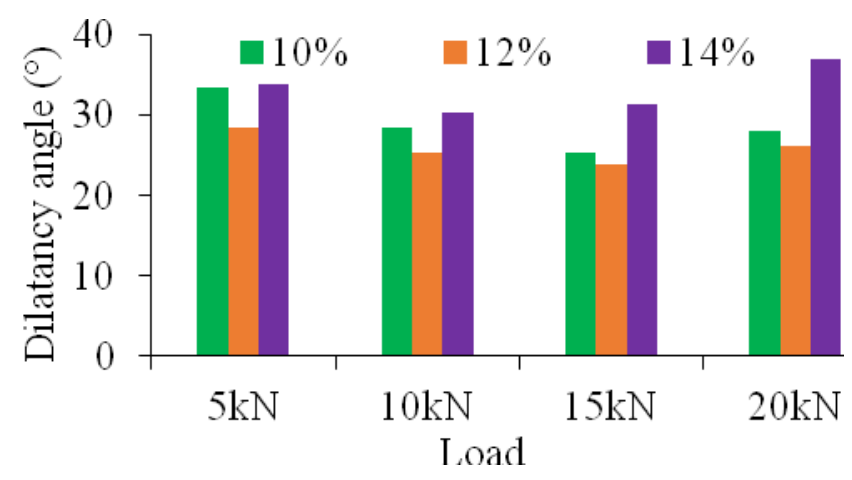

FIGURE 8. Dilatancy angle for beans.

We observed that the dilatancy angle $(\psi)$ values tend to decrease with the increase of moisture and load up to $15 \mathrm{kN}$, with subsequent increase in the next load, especially for the $14 \%$ content, reaching a maximum of $37^{\circ}$. This phenomenon agrees with STASIAK et al. (2013) that concluded that the mechanical properties of granular products might present a reduction in their values due to the increase of moisture. The fact of the increase recorded for the last load can be the result of accommodation of the material in the cell and that, if proven, will not be repeated in loads greater than this.

\section{CONCLUSIONS}

1. The modulus of Elasticity of agricultural products showed increase with the addition of loads and decrease as it increased the moisture content.

2. For the Poisson's ratio calculated for the loading stage $\left(v^{*}\right)$ and unloading $(v)$ showed an increase of their values with the increase of the load, for all moisture contents. The experimental Poisson's ratio $\left(v_{\text {exp }}\right.$.) showed a decrease of values with the increase of loading, regardless of moisture content.

3. The dilatancy angle of grains decreased with the increase of compressive load and moisture content of the material.

\section{ACKNOWLEDGEMENTS}

We thank to the National Council of Scientific and Technological Development (CNPq) for the scholarship granted; to the Study Groups in Silos (Silos) and to the Rural Buildings Studies and Ambience (RBSA), both from the Federal University of Campina Grande, for their support in favour of this research.

\section{REFERENCES}

AL HATTAMLEH, O. H.; AL-DEEKY, H. H.; AKHTAR, M. N. The consequence of particle crushing in engineering properties of granular materials. International Journal of Geosciences, v.10, n.4, p.1055-1060, setembro. 2013. http://dx.doi.org/10.4236/ijg.2013.47099 
CHAKRABORTY, T.; SALGADO, R. Dilatancy and shear strength of sand at low confining pressures. Journal of Geotechnical and Geoenvironmental Engineering, v.136, p.527-532, março. 2010. doi: 10.1061/_ASCE_GT.1943-5606.0000237

COSTA, C. A.; LOPES NETO, J. P.; NASCIMENTO, J. W. B.; DINIZ, M. J.; SILVA, V. R. Propriedades mecânicas e de fluxo de produtos agroindustriais. Revista Brasileira de Engenharia Agrícola e Ambiental, v.18, n.7, p.766-772, fevereiro. 2014.

GONZÁLEZ-MONTELLANO, C.; RAMÍREZ, Á.; GALLEGO, E.; AYUGA, F. Validation and experimental calibration of 3D discrete element models for the simulation of the discharge flow in silos. Chemical Engineering Science, v.66, n.7, p.5116-5126, julho. 2011.

doi:10.1016/j.ces.2011.07.009

GUSTAFSSON, G; HÄGGBLAD H. Å.; JONSÉN, P; MARKLUND, P. Determination of bulk properties and fracture data for iron ore pellets using instrumented confined compression experiments. Powde r Technology, v.241, n.1, p.19-27, junho. 2013. http://dx.doi.org/10.1016/j.powtec.2013.02.030

HORABIK, J.; MOLENDA, M. Mechanical properties of granular materials and their impact on load distribution in silo: a review. Scientia agriculturae bohemica, v.45, n.4, p.203-211, setembro. 2014. doi: 10.1515/sab-2015-0001

LOPES NETO, J. P.; NASCIMENTO, J. W. B.; SILVA, Rafael C.; COSTA, C. A. Powder flow criteria for design of vertical silo walls. Engenharia Agrícola, v.33, n.3, p.453-462, maio/junho. 2013.

MOLENDA, M.; STASIAK, M. Determination of the elastic constants of cereal grains in a uniaxial compression test. International of Agrophysics, v.8, n. 16, p.61-65, janeiro. 2002.

MOYA, M; AGUADO, P.J.; AYUGA, F. Mechanical properties of some granular agricultural materials used in silo design. International Agrophysics, v.27, n.1, p.181-193, janeiro. 2013. doi: 10.2478/v10247-012-0084-9

POLISH STANDARD. PN-89/B-03262. Concrete bins for storing granular materials and silage. Design rules, Polish, 1989.

RAMÍREZ, A; MOYA, M; AYUGA, F. Determination of the mechanical properties of powdered agricultural products and sugar. Particle \& Particle Systems Characterization, v.26, n.4, p.220230, janeiro. 2010. doi: 10.1002/ppsc.200800016

STASIAK, M.; MOLENDA, M.; RUSINEK, R.; HORABIK, J. Właściwości mechaniczne złoża nasion rzepaku wyznaczane w teście jednoosiowego ściskania. Acta Agrophysica, v.46, n.4, p.167$178,2001$.

STASIAK, M.; TOMAS, J.; MOLENDA, M.; RUSINEK, R.; MUELLER, P. Uniaxial compaction behaviour and elasticity of cohesive powders. Powder Technology, v.203, n.3, p.482-488, novembro. 2010. doi:10.1016/j.powtec.2010.06.010

STASIAK, M.; MOLENDA, M.; OPALIŃSKI, I.; BLASZCZAK, W. Mechanical Properties of Native Maize, Wheat, and Potato Starches. Czech Journal of Food Science, v.31, n.4, p.347-354, agosto. 2013.

WANG, XL; LI, JC. Simulation of triaxial response of granular materials by modified DEM.

Science China - Physics, Mechanics \& Astronomy, v.57, n.12, p.2297-2308, dezembro. 2014. doi: 10.1061/_ASCE_GT.1943-5606.0000237 